\title{
POLITYCZNY, EKONOMICZNY, SPOŁECZNY I RELIGIJNY KONTEKST LATYNOAMERYKAŃSKIEJ TEOLOGII WYZWOLENIA
}

\section{WSTĘP}

Teologia wyzwolenia zaistniała formalnie w roku 1968 podczas II Konferencji Generalnej Episkopatu Ameryki Łacińskiej (CELAM) w Medellin w Kolumbii, kiedy to w dokumencie końcowym obrad potwierdzono „uprzywilejowane traktowanie ubogich” przez Kościół latynoamerykański. Funkcję doradcy teologicznego na tej konferencji pełnił peruwiański duchowny, ówczesny profesor Wydziału Teologicznego Uniwersytetu Katolickiego w Limie ks. Gustavo Gutierrez. To właśnie od jego wydanej trzy lata później książki Teologia de la liberacion. Perspectivas (Lima 1971)1 zaczerpnął główne założenia i swoją nazwę „ruch teologiczno-społeczny”, który ogarnął całą Amerykę Południową

* Ks. Daniel Brzeziński - absolwent Papieskiego Instytutu Liturgicznego św. Anzelma w Rzymie oraz Instytutu Sacrum Ministerium Kongregacji ds. Duchowieństwa, adiunkt na Wydziale Teologicznym Uniwersytetu Mikołaja Kopernika w Toruniu, sekretarz redakcji „Studiów Płockich".

${ }^{1}$ Wydanie polskie na podstawie wydania z 1972 r.: G. Gutierrez, Teologia wyzwolenia. Historia, polityka i zbawienie, tłum. J. Szewczyk, Warszawa 1976. W niniejszym opracowaniu wykorzystano: D. Brzeziński, Źródła teologii wyzwolenia Gustavo Gutierreza. Studium teologiczne, mps, Płock-Warszawa 1990. 
i Środkową, stanowiąc poważne wyzwanie dla Kościoła przez blisko trzydzieści kolejnych lat. Sam zaś Gutierrez został uznany - obok H. Asmanna - za ojca teologii wyzwolenia. Do jej prekursorów zaliczono też R. Schaulla, J. Comblina i R. Alvesa. Inni główni przedstawiciele latynoamerykańskiej teologii wyzwolenia to: L. Boff, S. Galilea, J. L. Segundo, J. Scannone, J. Sobrino, P. Miranda, J. M. Bonino, E. Pironio, P. Casaldaliga, A. L. Trujillo oraz H. Camara. Jednak nie wszyscy oni - podzielając fundamentalną opcję na rzecz ubogich i dążąc do prawdziwego wyzwolenia człowieka, zgodnego z duchem chrześcijańskim przyjęli marksistowską analizę rzeczywistości. Zwłaszcza przedstawiciele hierarchii kościelnej zdecydowanie odcięli się od dążenia do wyzwolenia na drodze walki klas i przemocy oraz od redukcji problemu wyzwolenia jedynie do jego aspektu polityczno-społecznego ${ }^{2}$.

Teologia wyzwolenia, która powstała w konkretnych warunkach polityczno-społecznych i ekonomicznych Ameryki Łacińskiej jako protest przeciwko nim, pragnęła te dziedziny objąć swoją wyzwoleńczą działalnością. Postulowała radykalnie wyzwolenie, gdyż - jak podkreślał ks. Gustavo Gutierrez - kraje Ameryki Łacińskiej „są utrzymywane w stanie neokolonializmu"3. Przyczyną tej sytuacji jest wieloraka zależność krajów latynoamerykańskich od innych państw, zwłaszcza Stanów Zjednoczonych i krajów Europy Zachodniej. Przejawia się ona zarówno w układach politycznych, jak i w stosunkach gospodarczych panujących na kontynencie latynoamerykańskim. Ponadto jest wyraźnie widoczna w relacjach społecznych. Chodzi

${ }^{2}$ Zob. B. Mondin, Teologowie wyzwolenia, tłum. R. Borkowski, Warszawa 1988. W tym miejscu należy uściślić, że przynajmniej z dwóch powodów należałoby mówić raczej o teologiach wyzwolenia. Pierwszy z nich to odmienność kultury oraz sytuacji społecznej, politycznej i ekonomicznej państw Europy, Azji, Afryki czy Ameryki Łacińskiej, co sprawiło powstawanie wielu rodzimych teologii - zob. Teologowie Trzeciego Świata. Jedenaście szkiców biograficznych z Afryki, Azji i Ameryki Łacińskiej, H. Waldenfels (red.), thum. B. Kita, Warszawa 1987; M. Horoszewicz, Czarnoamerykańska teologia wyzwolenia, "Człowiek i Światopogląd" 168 (1979), nr 7, s. 82-110. Drugą przyczynę stanowi fakt, że nawet wyrosłe w tym samym klimacie społeczno-politycznym koncepcje teologiczno-pastoralne różniły się często między sobą do tego stopnia, że pozostawały we wzajemnej opozycji. Chodzi tu zarówno o konkretne poglądy w kwestiach społecznych czy politycznych, jak i o metody uprawiania teologii zob. J. Segundo, Dwie tendencje w "teologii wyzwolenia, tłum. A. Borowik, "Życie Katolickie" 1 (1985), s. 87-98; A. Młotek, Wśród różnych koncepcji teologii wyzwolenia, "Chrześcijanin w świecie" 76 (1979), nr 4, s. 34. Jezuicki teolog A. Hennely wyróżnił aż dziewięć typów teologii wyzwolenia: latynoamerykański, północnoamerykański feministyczny, murzyński, latynoski, afrykański, azjatycki, Pierwszego Świata, ekoteologiczny oraz teologię wyzwolenia religii światowych - zob. J. L. Allen, Papież Benedykt XVI. Biografia Josepha Ratzingera, tłum. R. Bartołd, Poznań 2005, s. 178; D. Brzeziński, Stolica Apostolska i kardynat Joseph Ratzinger wobec teologii wyzwolenia. Refleksje wokót watykańskich instrukcji z roku 1984 i 1986, „Studia Theologica Varsaviensia" 45 (2007), nr 2, s. 97-98.

${ }^{3}$ G. Gutierrez, Teologia, s. 116. 
tutaj o odniesienia polityczno-ekonomiczne w poszczególnych krajach Ameryki Łacińskiej, jak i na arenie międzynarodowej.

Aby uzyskać pełniejszy obraz tej „ziemi kontrastów" ${ }^{4}$, nie sposób nie odnieść się także do sytuacji religijnej krajów latynoamerykańskich lat siedemdziesiątych i osiemdziesiątych ubiegłego stulecia, gdyż i ona zdecydowanie wchodzi w zakres życia społecznego. Złożona i trudna sytuacja polityczna, gospodarcza, społeczna i religijna, będąc tłem wydarzeń w Ameryce Łacińskiej, stała się jednocześnie bezpośrednią przyczyną zaistnienia i rozwoju teologii wyzwolenia. W niej przede wszystkim należy upatrywać genezę nowego latynoamerykańskiego ruchu społeczno-politycznego.

Amerykę Łacińską nazwano „kontynentem, który stoi na wulkanie problemów społeczno-politycznych, ekonomicznych i wcale nie mniejszych w wymiarze całego kontynentu problemów istniejącego tam i działającego Kościoła" ${ }^{\prime 5}$. Aby wnikliwiej przyjrzeć się Sitz im Leben teologii wyzwolenia w Ameryce Łacińskiej, dokonamy sztucznego w pewnym sensie podziału, rozpatrując każdy z aspektów sytuacji egzystencjalnej Ameryki Łacińskiej niejako z osobna, choć latynoamerykańscy teologowie wyzwolenia wprost takiego podziału nie dokonywali, łącząc wyzwolenie ekonomiczne kontynentu ze społecznym i politycznym uniezależnieniem ${ }^{6}$. Widać to szczególnie, gdy tłumaczyli znaczenie pojęcia „rozwój”. Skłaniali się wówczas do rozumienia tego terminu jako całościowego procesu społecznego, obejmującego zarówno elementy ekonomiczne, jak i ściśle społeczne, polityczne oraz kulturowe. „To pojęcie akcentuje [bowiem] współzależność różnych czynników. Postęp w jednej dziedzinie - pisał Gutierrez - implikuje postęp w pozostałych i na odwrót: stagnacja w jednej opóźnia wzrost pozostałych"7. Zależność gospodarcza wiąże się z brakiem wolności

${ }^{4}$ Określenie użyte przez R. Laurentina, W Ameryce Eacińskiej po Soborze, tłum. G. Kania, Warszawa 1974, s. 7.

${ }^{5}$ Tak przed pierwszą podróżą Jana Pawła II do Ameryki Łacińskiej scharakteryzowali ten kontynent niektórzy dziennikarze; cyt. za: E. Kaczyński, Kontynent nadziei, „W drodze” 72 (1979), nr 8, s. 81. Problematykę złożonych przyczyn obecnej sytuacji politycznej, społecznej, gospodarczej, kulturalnej i religijnej Ameryki Łacińskiej w aspekcie historycznym podjęło wielu autorów, m.in. M. Szafrańska-Brandt, Historia Kościoła w Ameryce Środkowej, w: Jan Pawet II w Ameryce Środkowej. 2-10 marca1983 r. Przemówienia i homilie, J. Sobiepan (red.), Warszawa 1987, s. 185-206; E. B. Pike, Katolicyzm w Ameryce Eacińskiej, w: Historia Kościoła, R. Aubert (red.), t. 5, Warszawa 1985, s. 239-286; z marksistowskiego punktu widzenia: J. Drohojowski, La presencia del pasado, czyli obecność przeszłości, w: Ameryka Eacińska, L. Onichimowski (red.), Warszawa 1980, s. 38-69; R. Tokarczyk, Wspótczesne doktryny polityczne, Lublin 1987, s. 251 in.; Krótka historia Meksyku, A. Witkowska (red.), Warszawa 1986; sytuację Kościoła, relacje chrześcijaństwa do polityki i spraw społecznych w poszczególnych państwach Ameryki Łacińskiej szczegółowo opisał S. Markiewicz, Katolicyzm polityczny w Ameryce Łacińskiej 1968-1979, Warszawa 1981.

${ }^{6}$ Zob. G. Gutierrez, Teologia, s. 97.

${ }^{7}$ Tamże, s. 33. 
politycznej, obowiązek zaś rozszerzania wiary już w czasach konkwisty hiszpańskiej i portugalskiej łączono z kolonizacją i podbojem niechrześcijańskiej ludności tubylczej, co przynosiło określone korzyści ekonomiczne ${ }^{8}$. Jak więc rozwój jest całościowym procesem społecznym, tak i układy polityczno-społeczno-gospodarczo-kulturowe są stanem całościowym. Oddzielne ich omawianie uzasadnione jest jedynie ze względów metodologicznych.

\section{KONTEKST POLITYCZNY}

Obecna sytuacja polityczna w Ameryce Łacińskiej została ukształtowana w atmosferze walk narodowowyzwoleńczych rozgrywających się tu na początku XIX wieku. Wtedy to dotychczasowe wicekrólestwa zależne od Hiszpanii uzyskały niepodległość 9 . Wyzwoliły się wówczas także obszary pozostające pod rządami Portugalii ${ }^{10}$. Pod koniec XIX wieku na czoło państw amerykańskich wysunęły się Stany Zjednoczone, które poprzez uzależnienie gospodarcze zaczęły wpływać na politykę nowo utworzonych państw Ameryki Południowej i Środkowej. Dzisiaj - jak określa to wielu komentatorów - dawny kolonializm jawny został zastąpiony, obok kolonializmu ekonomicznego, ukrytym kolonializmem politycznym ${ }^{11}$. Zależność ekonomiczna bowiem ma decydujący wpływ na dominację społeczną i polityczną ${ }^{12}$.

Gutierrez, podobnie jak i inni teologowie, w momencie powstawania latynoamerykańskiej teologii wyzwolenia niewiele mówił wprost o uzależnieniu politycznym, ale poprzez rozważania na temat zależności finansowo-gospodarczej dawał wyraz swojemu przekonaniu o niewoli politycznej. Przejawiała się ona między innymi w represjach ze strony rządów w stosunku do osób, w tym duchownych, działających na arenie politycznej ${ }^{13}$. Przykładem rządów terroru i walki z wszelką opozycją była sytuacja w Brazylii w latach sześćdziesiątych XX wieku, kiedy do władzy doszła armia ${ }^{14}$. Wojsko sprawowało wówczas władzę w wielu krajach latynoamerykańskich, naruszając prawa człowieka w życiu

${ }^{8}$ Zob. M. Szafrańska-Brandt, Historia Kościoła, s. 185 in.

${ }^{9}$ Wicekrólestwa Hiszpanii: Nowa Hiszpania (Meksyk, kraje Ameryki Środkowej), Peru (Peru, Chile), Nowa Grenada (Wenezuela, Ekwador), La Plata (Argentyna, Paragwaj, Urugwaj, Boliwia).

${ }^{10}$ Tzn. Brazylia - w roku 1822.

${ }^{11}$ Zob. R. Laurentin, W Ameryce Eacińskiej, s. 7.

${ }^{12}$ Szerzej to zagadnienie omawia J. Rollet, Społeczne tło teologii wspótczesnej, tłum. A. Landman, Warszawa 1981, s. 29-31.

${ }^{13}$ Por. G. Gutierrez, Teologia, s. 112-113.

${ }^{14}$ Zob.: M. Bocheńska, Gdy sumienie nakazuje stanąć w obronie ludu, "Życie i Myśl” 239 (1974), nr 5, s. 33; R. Laurentin, W Ameryce Eacińskiej, s. 77; o terrorze kapłanów pisze Z. Marzec, Kontestatorzy w sutannach, "Nowe drogi” 430 (1985), nr 3, s. 122-123. 
politycznym swych państw ${ }^{15}$. W wielu krajach Ameryki Łacińskiej, gdzie od początku XX wieku zachodziły wielokrotne zmiany rządów i konstytucji ${ }^{16}$, rządzący utrzymywali się (i często utrzymują nadal) przy władzy nie tyle w wyniku aprobaty swych podwładnych, co na skutek posiadania dostatecznych środków zastraszenia i podziału opozycji ${ }^{17}$.

O takiej sytuacji w Chile w latach siedemdziesiątych ubiegłego stulecia kardynał Silva Henriquez powiedział, że „polityczne prześladowania i akty zemsty są duszy narodowej obce"18. O niesprawiedliwości, nienawiści i przemocy w Ameryce Łacińskiej mówił wiele Jan Paweł II, gdy zwracał się w czasie swych pielgrzymek do wiernych tego kontynentu. Ojciec Święty dostrzegał jednak - w przeciwieństwie do teologów wyzwolenia - obok przemocy ze strony rządzących i wyzyskujących, zło płynące także z walki rewolucyjnej. Idea takiej zaś walki rozwijała się w Ameryce Łacińskiej głównie w latach siedemdziesiątych XX wieku. Sytuacja polityczna tego okresu nie była pomyślna z wielu względów. Nie udało się zrealizować programu modernizacji kapitalizmu, nie przyspieszono wzrostu gospodarki, a system polityczny republiki burżuazyjnej stanął w obliczu kryzysu ${ }^{19}$. Wobec takiego stanu teologowie wyzwolenia domagali się zmiany dotychczasowych układów politycznych. Punkt zwrotny w najnowszej historii Ameryki Łacińskiej stanowiła, według Gutierreza, rewolucja kubańska, która zwyciężyła wojskowo-policyjną dyktaturę Batisty ${ }^{20}$. Ojciec teologii wyzwolenia uważał, że rewolucja taka powinna objąć cały kontynent, gdyż lokalne tylko zrywy mają niewielkie szanse powodzenia.

Radykalne przedsięwzięcia ze strony mas, często wzorowane na przewrocie na Kubie, wywoływały reakcje obrońców starych struktur, działających w sposób bezkompromisowy i niejednokrotnie brutalny. Te niewielkie ekipy rządzące, skupiające w swych rękach całą władzę polityczną, pozbawiały narody możliwości

${ }^{15}$ Zob. E. Kaczyński, Kontynent, s. 92.

${ }^{16}$ Zob. M. Novak, Utopia teologów wyzwolenia, tłum. J. Neckar, „W drodze” 153-154 (1986), nr 5-6, s. 78.

${ }^{17}$ Częste przewroty polityczne, zwykle bezkrwawe, dokonywane przez wojsko i na ogół w dni świąteczne dla zaskoczenia społeczeństwa, były szczególną cechą latynoamerykańskich przewrotów ustrojowych. Od uzyskania niepodległości przez kraje Ameryki Łacińskiej naliczono ponad tysiąc takich przewrotów, które zwykle nie przynosiły żadnych zmian ustrojowych, choć wiele obiecywały - zob. R. Tokarczyk, Wspótczesne doktryny, s. 251-252.

${ }^{18}$ Zob. K. K., Kościót i państwo w Chile, „Myśl społeczna” 2 (1975), s. 5; z kolei o reżimie wojskowym w Boliwii i konflikcie Kościoła z państwem pisał L. Załęski, W Boliwii. Konflikt między Kościołem a państwem, „Myśl Społeczna” 32 (1975), s. 5.

${ }^{19}$ Zob. M. Chmara, "Ludy świadkowie", "ludy nowe" i "ludy przeszczepione”, w: Ameryka Eacińska, s. 210 in.

${ }^{20}$ Zob. G. Gutierrez, Teologia, s. 96 in. Problemy rewolucji na Kubie oraz cały kontekst polityczno-społeczny Ameryki Łacińskiej widziany z pozycji marksisty podejmuje książka: Fidel i religia. Rozmowy z bratem Betto, tłum. J. Perlin i M. Dołgolewska, Warszawa 1986. 
decydowania o własnym losie ${ }^{21}$. Były także gotowe korzystać z interwencji zbrojnej z zewnątrz, aby utrzymać reżim. Gutierrez uważał, że taki układ władzy politycznej ma wpływ, obok innych przyczyn, na brak „upolitycznienia” społeczeństw latynoamerykańskich, co wyraża się brakiem zainteresowania sferą polityczną, szczególnie w kręgach chrześcijańskich, oraz pomijaniem politycznych akcentów Ewangelii. Należy jednak zaznaczyć, że pomimo akcentowania politycznego wymiaru rzeczywistości, niektórzy teologowie wyzwolenia mieli świadomość, że jedną z pokus reprezentowanej przez nich orientacji, było wyolbrzymienie aspektu politycznego problemów dotyczących ucisku i wyzwolenia. Dlatego Leonardo Boff i jego brat Clodovis zwracali uwagę, by nie odbywało się to kosztem "głęboko ludzkich i ewangelicznych wymiarów, jak przyjaźń, przebaczenie, sens wolnego czasu i święta, dialog z wszystkimi ludźmi, wrażliwość na sztukę i bogactwa duchowe" ${ }^{\prime 22}$.

\section{KONTEKST EKONOMICZNY}

O sytuacji ekonomicznej decyduje stopień rozwoju gospodarczego danego państwa. Gutierrez dostrzegał, że w Ameryce Łacińskiej polityka rozwojowa proponowana krajom biednym w celu przezwyciężenia zacofania ekonomicznego miała wiele wad $^{23}$. Nie były nią zainteresowane rządy tych państw, a termin „doktryna rozwoju” przybrał sens pejoratywny. Według peruwiańskiego teologa był on synonimem reformizmu i modernizacji, które Gutierrez uważał za przedsięwzięcia skuteczne tylko na krótko i nieprzynoszące rzeczywistej poprawy stanu gospodarki ${ }^{24}$. Dlatego też postulował walkę krajów biednych o zniesienie dominacji krajów zamożnych, z możliwością rewolucji włącznie, gdyż istniejącą niesprawiedliwość w stosunkach gospodarczych i społecznych - wobec nieskuteczności strategii rozwoju - zniosłaby jedynie radykalna rewolucja społeczna.

Idea wejścia Ameryki Łacińskiej na drogę samodzielnego rozwoju gospodarczego w latach pięćdziesiątych ubiegłego wieku, sformułowana teoretycznie przez Komisję Gospodarczą ONZ dla Ameryki Łacińskiej, nie zdołała wyeliminować panującego systemu gospodarczego, a wręcz przeciwnie, przyczyniła się - według Gutierreza - do jego umocnienia ${ }^{25}$. Na potwierdzenie swej opinii

${ }^{21}$ Zob. G. Gutierrez, Teologia, s. 56-59.

${ }^{22}$ L. Boff, C. Boff, Niektóre tematy teologii wyzwolenia, „W drodze” 172 (1987), nr 12 , s. 35-36.

${ }^{23}$ Zob. G. Gutierrez, Teologia, s. 34 in.

${ }^{24}$ Gutierrez, obok Alvesa, Comblina, Segundo, Assmanna i innych, współdziałał w tej próbie przezwyciężenia kryzysu ekonomicznego, usiłując sformułować teologiczne podstawy teorii rozwoju - por. B. Mondin, Teologowie, s. 31.

${ }^{25}$ Zob. G. Gutierrez, Teologia, s. 89 in. Dążenia do integracji gospodarki latynoamerykańskiej w celu jej poprawy natrafiały na szereg trudności. Zaliczano do nich istnienie 
teolog z Limy przytacza słowa jednego z rzeczników owej doktryny rozwoju F. Herrery, który stwierdził, że „w drugiej połowie lat sześćdziesiątych [XX wieku] przepaść między obydwoma światami powiększyła się, zamiast się zmniejszyć, jak oczekiwano"26. Optymizm lat pięćdziesiątych zastąpiła więc pesymistyczna diagnoza realiów lat sześćdziesiątych.

Gutierrez uważał, że doktryna rozwoju nie uwzględniała poważnych problemów przyszłości, za mało brała pod uwagę czynniki polityczne oraz zestawiała statystycznie społeczeństwa Ameryki Łacińskiej ze społeczeństwami rozwiniętymi, podczas gdy - jak stwierdził T. Dos Santos - „nie ma żadnej historycznej możliwości, żeby stały się one społeczeństwami, które osiągną ten sam stopień rozwoju co społeczeństwa rozwinięte. Czas historyczny nie jest jednoliniowy"27.

Zacofanie Ameryki Łacińskiej jest konsekwencją rozwoju i ekspansji krajów stojących wysoko pod względem gospodarczym. Jest ono - jak określali to teologowie wyzwolenia - "historycznym produktem ubocznym” rozwoju krajów kapitalistycznych ${ }^{28}$. Sytuacja ekonomiczna państw latynoamerykańskich kształtowała się pod wpływem kolonizacji hiszpańskiej i portugalskiej. Kopalnie i plantacje tych krajów stanowiły dopełnienie i przedłużenie gospodarki państw, które Gutierrez nazwał centralnymi ${ }^{29}$. Tej zależności nie były (i wciąż nie są) w stanie znieść tendencje rozwijania rodzimego przemysłu, gdyż wiąże się go z kapitałem międzynarodowym, wplatając w interesy wielkich, wielonarodowych towarzystw gospodarczych ${ }^{30}$.

Swoje uwagi na temat sytuacji ekonomicznej Ameryki Południowej i Środkowej Gutierrez konkluduje stwierdzeniem, że „autonomiczny rozwój latynoamerykański jest nierealny w ramach międzynarodowego systemu ka-

zadawnionych niechęci między wieloma krajami, spory terytorialne, a przede wszystkim różnice między potencjałami gospodarczymi poszczególnych państw. Integracji przemysłu bały się małe kraje, gdyż mogło to pociągnąć za sobą nowe uzależnienia. Duże nadzieje wiązano z działalnością Latynoamerykańskiego Systemu Gospodarczego, organizacji założonej w październiku 1975 r.; zob. Z. Dobosiewicz, A. M. Żeromski, Nowoczesność i tradycja, w: Ameryka Eacińska, s. 118 i 136. Na XV Sesji Komisji Gospodarczej ONZ dla Ameryki Łacińskiej w 1973 r. delegat Chile wyraził pogląd, że państwa nielatynoamerykańskie: Francja, Holandia, USA i Wielka Brytania, które są członkami komisji od 1948 r. powinny być pozbawione członkostwa tej regionalnej organizacji, gdyż Ameryce Łacińskiej potrzebny jest własny międzynarodowy organizm gospodarczy; zob. J. E. Osmańczyk, Encyklopedia ONZ i stosunków międzynarodowych, Warszawa 1986, s. 246.

${ }^{26}$ G. Gutierrez, Teologia, s. 89.

${ }^{27}$ Tamże, s. 91.

${ }^{28}$ Zob. tamże, s. 92.

${ }^{29}$ Zob. tamże, s. 93.

${ }^{30}$ Gutierrez zwraca w tym miejscu uwagę, że o takich zależnościach mówili już Hobson, Róża Luksemburg, Lenin oraz Bucharin, formułując teorię imperializmu i kolonializmu. 
pitalistycznego"31. Musi nastąpić wyzwolenie spod dominacji narzucanej przez kapitalistyczne mocarstwa. Według V. Cosmao przekazywanie przez te państwa technologii i licencji krajom zacofanym nie przyniosło im pożytku, gdyż strona przyjmująca nowoczesne nawet technologie nie była w stanie czerpać z nich korzyści. „Chorowała [bowiem] od wewnątrz” i została „porażona jej dynamika i organizacja"32. M. Novak zaś zwrócił uwagę na fakt, że choć nie brak było w przeszłości w Ameryce Łacińskiej ludzi ze zdolnościami ekonomicznymi, to jednak mieli oni zbyt małe poparcie ze strony Kościoła. Ponadto kultura tych terenów, charakteryzując się powszechną niechęcią do handlu, także nie sprzyjała rozwojowi ekonomicznemu ${ }^{33}$. M. Novak jest zgodny z Gutierrezem w kwestii wyzyskiwania gospodarczego narodów latynoamerykańskich poprzez nieuczciwe warunki handlowe narzucone z zewnątrz przez międzynarodowe korporacje. Przytacza on ogólnie przyjęte przekonanie o szukaniu przez mocarstwa finansowe własnych interesów ekonomicznych i politycznych ${ }^{34}$.

System kapitalistycznych inwestycji pozbawiał Amerykę Łacińską zasobów naturalnych i związanych z ich wydobyciem korzyści finansowych, obdarzając nimi kraje wysokorozwinięte ${ }^{35}$. Ponadto gospodarka państw środkowoamerykańskich w omawianym okresie silnie uzależniona była od wahań cen eksportowanych produktów monokulturowych, dlatego nie było mowy o jakimkolwiek planowaniu ${ }^{36}$.

Różnice w rozwoju gospodarczym ujawniały się nie tylko między Ameryką Łacińską a krajami Europy Zachodniej czy Stanami Zjednoczonymi, lecz również między samymi państwami kontynentu: między „,względnym bogactwem Argentyny, Panamy, Wenezueli i ubóstwem innych, jak Boliwia, Ekwador lub Haiti"37. Były one wyraźnie widoczne w zestawieniach produktów narodowych brutto przypadających na jednego mieszkańca ${ }^{38}$.

31 Tamże s. 92.

${ }^{32}$ V. Cosmao, Problematyka teologii wyzwolenia, tłum. W. Unolt, „W drodze” 153-154 (1986), nr 5-6, s. 38.

${ }^{33}$ M. Novak, Utopia, s. 74.

${ }^{34}$ Zob. tamże, s. 76. Na przykład w przeświadczeniu wielu Brazylijczyków owe międzynarodowe korporacje stały u podstaw zadłużenia, inflacji i stagnacji rozwoju przemysłowego ich państwa, pomimo faktu, że Brazylia znajdowała się w swoim czasie na ósmym miejscu w świecie pod względem produkcji przemysłowej - por. J. A. Kłoczowski, Dwie favele, „W drodze" 172 (1987), nr 12, s. 25.

${ }^{35}$ Por. R. Laurentin, W Ameryce Eacińskiej, s. 7.

${ }^{36}$ Te produkty to głównie kawa, kakao i banany - zob. M. Szafrańska-Brandt, Historia Kościoła, s. 193.

${ }^{37}$ R. Laurentin, W Ameryce Eacińskiej, s. 8.

${ }^{38}$ Pod tym względem kraje Ameryki Łacińskiej dzielono na cztery grupy: a. kraje najbiedniejsze o produkcie narodowym brutto na 1 mieszkańca poniżej 500 dolarów (Haiti, Boliwia, Salvador, Ekwador, Paragwaj); b. kraje biedne: 500-100 dolarów (Kolumbia, Gwa- 
Gdy mowa o różnicach gospodarczych, trzeba zwrócić uwagę na jeszcze jeden rodzaj rozbieżności: tę pomiędzy prężnym, nowoczesnym sektorem gospodarki (zmechanizowane plantacje, nowoczesne fabryki) a gospodarką tradycyjną z prymitywnymi wciąż technikami produkcji ${ }^{39}$, czy też pomiędzy intensywną gospodarką plantacyjną a ekstensywnym charakterem gospodarki latyfundiów ${ }^{40}$. Ubożenie gospodarcze, zwłaszcza na wsi, obok ekstensywnego sposobu produkcji rolnej, powodowała również permanentna parcelacja gruntów i powstawanie gospodarstw karłowatych, co dokonywało się ze względu na dynamiczny przyrost naturalny ${ }^{41}$. Słabo rozwinięte było (i wciąż pozostaje) nie tylko rolnictwo, lecz również przemysł, gdzie wysokiemu poziomowi jednych jego gałęzi towarzyszy niedorozwój lub wręcz brak wielu innych, a rzeczywistą (nie tylko pozorną) industrializację hamuje kontrola obcego kapitału.

\section{KONTEKST SPOŁECZNY}

Teologowie wyzwolenia, omawiając nędzę i zacofanie Ameryki Łacińskiej, zwracali uwagę głównie na aspekt społeczny tego stanu. Ich refleksję teologiczną zrodziły przede wszystkim „przeżycia wspólnych wysiłków zmierzających do zlikwidowania [...] niesprawiedliwości i zbudowania innego społeczeństwa, bardziej wolnego i ludzkiego” oraz solidarność z uciskanymi ${ }^{42}$. Uważali, że „walka o zbudowanie sprawiedliwego i braterskiego społeczeństwa, w którym ludzie mogliby żyć z godnością i być twórcami własnego losu”43 była i jest najważniejszym zadaniem człowieka w historii, szczególnie w krajach uciskanych.

Podobnie jak w przypadku genezy sytuacji politycznej, korzeni obecnych układów społecznych w Ameryce Łacińskiej trzeba szukać w czasach iberyjskiej kolonizacji, która pociągnęła za sobą jego penetrację i podbój społeczności tubylców ${ }^{44}$. Z podbitymi ludami konkwistadorzy niejednokrotnie obchodzili się okrutnie, traktując je niewolniczo ${ }^{45}$. Z czasem w miejsce ludności tubylczej,

temala, Nikaragua, Peru, Kostaryka, Chile, Brazylia); c. kraje średnio rozwinięte: 1000-1500 dolarów (Panama, Meksyk, Urugwaj); d. kraje najbardziej rozwinięte gospodarczo: ponad 1500 dolarów (Wenezuela, Argentyna i większość państw karaibskich; zob. Z. Dobosiewicz, A. M. Żeromski, Nowoczesność, s. 72.

${ }^{39}$ Zob. tamże, s. 72-73.

${ }^{40}$ Zob. tamże, s. 81 .

${ }^{41}$ Zob. tamże, s. 82.

${ }^{42}$ Zob. G. Gutierrez, Teologia, s. 7.

${ }^{43}$ Tamże, s. 8.

${ }^{44}$ Zob. M. Szafrańska-Brandt, Historia Kościoła, s. 185 in.; M. Maliński, Pielgrzymka do świata, Warszawa 1987, s. 295; B. de Las Casas, Krótka relacja o wyniszczeniu Indian, tłum. K. Niklewiczówna, Poznań 1988.

${ }^{45}$ Zob. J. Różański, W kleszczach politycznej dialektyki. Kościót w Chile, "Misyjne Drogi” 20 (1987), nr 4, s. 12. 
wyniszczonej niewolniczą pracą na plantacjach i w kopalniach, sprowadzono ludność murzyńską z Afryki, by i ona stała się tanią siłą roboczą.

Dzisiaj Ameryka Łacińska jest jedynym kontynentem ludów wyzyskiwanych, na którym chrześcijanie stanowią większośćc ${ }^{46}$. Teologia wyzwolenia pragnęła stać się, jak stwierdzał Gutierrez, „protestem przeciw deptaniu godności ludzkiej i walką przeciw ograbianiu większości ludzi”47, którzy „są świadomi niemożliwych do przyjęcia warunków, w jakich żyją"48. W doktrynie teologów wyzwolenia przebijała się więc kwestia coraz głębszego budzenia świadomości uciskanych oraz potrzeby przechodzenia od tzw. świadomości naiwnej do świadomości krytycznej. Proces ten jest charakterystyczny dla tzw. pedagogiki uciskanych, której próby opracowania podjął się P. Freier. Człowiek uciskany, będąc świadomy swej sytuacji, staje się mniej zależny i swobodniejszy w przekształcaniu i budowaniu społeczeństwa ${ }^{49}$. Ze stanem świadomości naiwnej trzeba walczyć. Człowiek ma być w pełni świadom procesu historycznego i swego w nim miejsca. Mając tę świadomość, kraje biedne nie chciały kształtować własnej struktury na wzór krajów bogatych między innymi również dlatego, że coraz bardziej przekonywały się, że status tych ostatnich był owocem niesprawiedliwości i przymusu. Gutierrez postulował więc stworzenie nowego społeczeństwa, które byłoby społeczeństwem socjalistycznym i w którym drogą rewolucji społecznej do władzy doszłaby klasa wyzyskiwana. Na korzyść rewolucji krytykował doktrynę rozwoju. Uważał, że dopiero wyzwolenie rozważane w takim świetle „zaczyna się okazywać czymś bardziej właściwym i bogatszym w treści ludzkie" ${ }^{\prime 50}$.

Jak wyglądała (i niestety w wielu przypadkach wciąż wygląda) sytuacja społeczna, z której Gutierrez i inni pragnęli wyzwolić narody latynoamerykańskie i którą krytykowali nie tylko teologowie wyzwolenia, lecz także Kościół katolicki? Ten ostatni jednak proponował „wyzwolenie społeczne bez przemocy i nienawiści”"51. Najbardziej chyba wstrząsający jej przejaw to niedożywienie ludności na wielu obszarach kontynentu. W 1975 roku liczba głodujących wynosiła ponad 100 milionów ludzi. Pod koniec lat osiemdziesiątych XX wieku sięgała ona 300 milionów osób ${ }^{52}$.

${ }^{46}$ Zob. G. Gutierrez, Teologia, s. 8-9.

${ }^{47}$ Tamże, s. 25.

${ }^{48}$ Tamże, s. 30.

${ }^{49}$ Zob. tamże, s. 99.

${ }^{50}$ Tamże, s. 34-36.

${ }^{51}$ Zob. Homilia Jana Pawła II wygłoszona w Santo Domingo 11 października 1984 r., „W drodze" 153-154 (1986), nr 5-6, s. 33-35.

52 Zob. M. Chmara, „Ludy świadkowie”, s. 156-158. 
Problemy społeczno-ekonomiczne pogłębiały żywiołowe ruchy migracyjne, wynikające $z$ wysokiego przyrostu naturalnego ${ }^{53}$. Był to proces niekontrolowany, powodujący powstawanie wokół wielkich ośrodków miejskich dzielnic nędzy, w których mieszkało często 30-40\% ogółu ludności ${ }^{54}$. I dzisiaj, podobnie jak w okresie dynamicznego rozwoju teologii wyzwolenia, ludność tych dzielnic często tworzy wspólnoty, w których każdą uzyskaną rzecz lub zarobione pieniądze oddaje się do dyspozycji grupy ${ }^{55}$. Owe wspólnoty, na czele których stoi zwykle duszpasterz, zwane wspólnotami podstawowymi - obok ewangelizacji, katechizacji czy po prostu zwykłej nauki czytania i pisania - rozwijają działalność charytatywną, przychodząc z pomocą najbardziej potrzebującym. Z mieszkańcami faveli Vidigal w Rio de Janeiro spotkał się Jan Paweł II w czasie swojej wizyty w Brazylii w 1980 roku. Ojciec Święty przekazał wtedy na jej potrzeby miejscowemu proboszczowi złoty pierścień, który otrzymał od Pawła VI podczas uroczystości wręczenia biretu kardynalskiego w roku $1967^{56}$. Podobnie uczynił wcześniej arcybiskup Refice dom Helder Camara, rzecznik ubogich, oddając złoty pierścień i krzyż biskupi papieżowi w zamian za pierścień stalowy i krzyż drewniany oraz przeznaczając na cele społeczne swój dom biskupi i przenosząc się do skromnego mieszkania ${ }^{57}$.

Obok ubóstwa mas w Ameryce Łacińskiej spotykamy bogactwo nielicznych ${ }^{58}$. Wzbogacili się oni często kosztem ubogich chłopów albo rugowanych Indian. Takich kontrastów jest na kontynencie latynoamerykańskim mnóstwo ${ }^{59}$. W Brazylii na przykład w stanach południowych obok bardzo wykształconych mieszka 50\% analfabetów, w stanach północnych zaś analfabeci to 95\% ogółu

${ }^{53}$ Pod adresem społecznego problemu migracji wewnętrznych skierowane było pytanie hasło X Kongresu Eucharystycznego w Fortalezie w Brazylii w 1980 roku „Para onde vais?” (Dokąd idziesz?). Jan Paweł II w homilii inaugurującej Kongres pytanie to zadał Kościołowi w Brazylii - zob. Jan Pawet II w Brazylii 30 czerwca-11 lipca 1980 r. Przemówienia, homilie, modlitwy, oprac. A. Podsiad, Warszawa 1985, s. 270-276.

${ }^{54}$ Takie dzielnice nędzy, w których ludzie żyją ze śmietników, mieszkając w kartonowych szałasach, np. wokół Rio de Janeiro są nazywane barriada, allampa, villa miseria lub favela - zob. J. A. Kłoczowski, Dwie favele, s. 20-30; M. Maliński, Pielgrzymka, s. 98.

${ }^{55} \mathrm{O}$ takiej wspólnocie ubogich w Limie (Peru) mówił o. D. Byrne, ówczesny generał zakonu dominikanów w rozmowie z W. Unoltem i J. Grzegorczykiem, Co jest ważne dla Kościoła, „W drodze” 153-154 (1986), nr 5-6, s. 12.

${ }^{56}$ Zob. Jan Pawet II Papież Pielgrzym, red. W. Tkaczuk, Warszawa 1980, s. 98.

${ }^{57}$ Zob. E. Wojtusiak, Chrystianizm a problemy rewolucji społecznej, „Kultura i Społeczeństwo" 21 (1977), s. 118; sylwetkę abpa Helder Camary przybliża także R. Laurentin, W Ameryce Eacińskiej, s. 82-90.

${ }^{58}$ Zob. R. Laurentin, W Ameryce Eacińskiej, s. 8.

${ }^{59} \mathrm{~W}$ kategoriach kontynentu kontrastów ujmuje Amerykę Łacińską m.in. G. M. Grotti, Misje w Ameryce Łacińskiej, w: Misje po Soborze Watykańskim II, W. Kowalak, K. Rybacka, B. Skóra, F. Zapłata (red.), tłum. I. Pluszczyk, B. Wodecki, Płock 1981, s. 114-121; także R. Laurentin, W Ameryce Eacińskiej, s. 7-9. 
mieszkańców ${ }^{60}$. Podobnie bardzo małe grupy w społeczeństwach latynoamerykańskich stanowią właściciele olbrzymich majątków ziemskich. Natomiast zdecydowana większość to - traktowani prawie jak niewolnicy - rolnicy bez ziemi $^{61}$. W Gwatemali w czasach największego rozwoju teologii wyzwolenia 0,7\% ludności posiadało 50\% ziemi ${ }^{62}$. W Brazylii 60\% ludności to nędzarze, podczas gdy stolica kraju Brasilia już w ubiegłym stuleciu była uważana za miasto na miarę XXI wieku ${ }^{63}$. Według danych zebranych w latach osiemdziesiątych ubiegłego wieku przez Bank Rozwoju 5\% Brazylijczyków dysponowało aż 40\% dochodu narodowego, 40\% zaś - tylko 8\%. Ta dysproporcja przejawiała tendencję zwyżkową, gdyż wielu robotników na skutek reorganizacji przemysłu traciło pracę $^{64}$. O ich losie decydowało wąskie grono właścicieli fabryk. Owa dominacja jednych klas społecznych nad innymi stanowiła podstawę niesprawiedliwego porządku, którego zmiana - według teologów wyzwolenia - stała się „największym wyzwaniem naszych czasów"65. Zwracali oni uwagę, że "społeczny brak równowagi, polityczne napięcia i nędza dla wielu” przy „postępie i bogactwie dla nielicznych" są konsekwencją gospodarki kapitalistycznej ustanawiającej tzw. centrum i peryferie, w których struktura społeczna różni się zasadniczo ${ }^{66}$. W państwach peryferyjnych warunki nędzy, wyobcowania i wyzysku stwarzają pilną potrzebę ekonomicznego i społecznego wyzwolenia ${ }^{67}$. Ponadto skupienie kapitału w prywatnych rękach wprowadza rozdźwięk między kapitałem a pracą, między posiadającymi a robotnikami, jest przyczyną wyzysku człowieka przez człowieka. Stąd Gutierrez opowiadał się za społeczną własnością środków produkcji, charakterystyczną dla gospodarki socjalistycznej ${ }^{68}$. Podobnie L. Boff twierdził, że w obliczu takiej sytuacji nie wystarcza katolicka nauka o społeczeństwie, lecz trzeba analizy marksistowskiej. Trzeba na świat spojrzeć oczyma ubogich $^{69}$. W ten sposób w latach sześćdziesiątych XX wieku postąpiła grupa 300 księży brazylijskich, potępiając „niesprawiedliwe płace, wyzysk i taktykę morzenia głodem”, 120 zaś księży boliwijskich „wypowiedziało się negatywnie

${ }^{60}$ Zob. M. Maliński, Pielgrzymka, s. 98.

61 Tamże, s. 18.

62 Tamże, s. 187.

63 Tamże, s. 98.

${ }^{64}$ Dramatyczne warunki pracy boliwijskich górników i ich położenie po zamknięciu w 1986 r. nierentownych kopalni opisuje M. Głogowski, Uśmiech nie gości na Altiplano, „Kontynenty” 3286 (1988), nr 3, s. 4. Szczegółowej charakterystyki klasowego społeczeństwa Ameryki Łacińskiej dokonuje M. Chmara, Ludy świadkowie, s. 158-183.

65 Zob. G. Gutierrez, Teologia, s. 58.

${ }^{66}$ Centrum to państwo, od którego zależne są państwa-peryferie.

${ }^{67}$ Zob. G. Gutierrez, Teologia, s. 92.

${ }^{68}$ Zob. tamże, s. 118-121.

${ }^{69}$ Zob. (b. a.), Teologia wyzwolenia. W poszukiwaniu przyczyn nędzy $i$ ucisku, "Argumenty" 45 (1984), s. 13. 
w kwestii niemożliwości decydowania przez wyzyskiwanych o swych losach i nieuczestniczenia w zasobach społeczno-gospodarczych"70.

Skomplikowana sytuacja społeczna - oprócz przyczyny głównej, jaką jest zniewolenie większości mieszkańców Ameryki Łacińskiej przez czynniki zewnętrzne - ma jeszcze inne powody. Jednym z nich jest niewątpliwie swoista mentalność tubylców. Indianin boliwijski czy kabokl brazylijski w zasadzie nie odczuwają potrzeby pracy i poczucia odpowiedzialności za siebie, swoją rodzinę czy za naród. Zdarza się i tak, że ludzie ci opuszczają swoje dzieci lub zatruwają je kokainą ${ }^{71}$.

Szukając przyczyn niewłaściwych struktur społecznych narodów latynoamerykańskich, Gutierrez wskazywał również na fakt powiązania części Kościoła z dzierżącymi władzę gospodarczą i polityczną. W tym duchu został zredagowany list otwarty do Pawła VI, podpisany m.in. przez biskupa G. Campesa i matkę ks. C. Torresa, a także oświadczenie „Dlaczego nie zgadzamy się", w którym grupa radykalnie usposobionych chrześcijan wystąpiła z ostrym protestem przeciw planowanej przez Pawła VI wizycie w Ameryce Łacińskiej. W oświadczeniu tym można było przeczytać:

Sama obecność Pawła VI obok oligarchów i wyzyskiwaczy będzie oznaczać ratyfikację przymierza między Kościołem i reakcyjnymi siłami kierowniczymi, skupiającymi władzę wojskową i ekonomiczną [...]. Pragnie się po prostu, by papież ściskał dłonie morderców ks. Camilo Torresa i 'che' Guevary ${ }^{72}$.

Stwierdzenie, że Kościół w Ameryce Łacińskiej związał się z klasą wyzyskiwaczy, posłużył Gutierrezowi jako argument przeciw proponowanej przez Kościół tzw. teologii dwóch płaszczczyzn, oddzielającej duchową sferę życia ludzkiego od sfery doczesnej. Teologowie wyzwolenia zarzucali Kościołowi opowiadającemu się za takim rozwiązaniem niekonsekwencję: $\mathrm{z}$ jednej strony głoszenie oddzielenia obu sfer, a z drugiej ingerencję w sferę doczesną. Nota bene sami teologowie wyzwolenia uważali ową ingerencję za rzecz normalną i wręcz konieczną w procesie wyzwalania człowieka. Zresztą - według nich jej brak w pewnym momencie doprowadził do kryzysu świeckich ruchów apostolskich, opartych na modelu oddzielnych płaszczyzn ${ }^{73}$. Gutierrez oskarżał Kościół o związek z klasą posiadającą, „legalizujący - jak pisał - rządy dyktatorskie

${ }^{70}$ Zob. G. Gutierrez, Teologia, s. 116.

${ }^{71}$ Zob. S. Budzyński, J. Fijor, Przed wizyta Jana Pawła II w Ameryce Eacińskiej, „Kierunki" 4 (1985), s. 3.

${ }^{72}$ Por. S. Markiewicz, Katolicyzm polityczny, s. 33-34. W podobny sposób na zjeździe Ruchu Katolickiego im. Camilo Torresa w lipcu 1968 r. zredagowany został list pt. „Wasza Świątobliwość, proszę nie jechać do Kolumbii" - zob. tamże, s. 36-37.

${ }^{73}$ Zob. G. Gutierrez, Teologia, s. 72-73. 
i uciskające”"74 . „Religia chrześcijańska - czytamy w przytoczonym przez niego fragmencie jednego z dokumentów CELAM - służyła i w dalszym ciągu służy, jako ideologia usprawiedliwiająca dominację możnych. W Ameryce Łacińskiej chrześcijaństwo było religią na usługach systemu [...], hamowało ludowy protest przeciwko niesprawiedliwemu i uciskającemu systemowi"75. Kościół - twierdził Gutierrez - powinien „interweniować bardziej bezpośrednio i porzucić sferę lirycznych hasel"76. Gdy taką postawę Kościoła można było zaobserwować, „wzbudziło [to] zaniepokojenie wśród beneficjantów i obrońców kapitalistycznego społeczeństwa, którzy nie mogą już polegać na tym, co dotychczas było - świadomie czy nieświadomie - jedną z ich głównych ostoi"77. Trzeba w tym miejscu odnotować, że inny teolog wyzwolenia, ks. J. Sobrino z Salwadoru, w latach osiemdziesiątych ubiegłego stulecia jednak dostrzegał, że

Kościół zaczyna solidaryzować się z ubogimi w pracy i walce o ich integralne wyzwolenie. [...] Kościół latynoamerykański - mówił Sobrino trzeba zachęcić, by naprawdę wybierał ubogich, by nie lękał się tego. Skandal Ameryki Łacińskiej polega na tym, że ciemiężyciele, dyktatorzy, ludzie władzy, ci, którzy torturują chrześcijan, sami też podają się za chrześcijan. Kościół powinien niezwłocznie pełnym głosem oznajmić, że nie jest po ich stronie, że nie jest $\mathrm{z}$ tego świata ${ }^{78}$.

Gutierrez nawoływał do zerwania z Kościołem konserwatywnym, podkreślając, iż Kościół w Ameryce Łacińskiej był wyraźnie podzielony w kwestii rozumienia procesu wyzwolenia i ustosunkowania się do niego. Większość oficjalnych przedstawicieli Kościoła - według Gutierreza - związana była na wiele różnych sposobów z panującym porządkiem społecznym. Konflikt w łonie samego Kościoła brał się więc stąd, że „niektórzy chrześcijanie znaleźli się wśród uciskanych i prześladowanych, a niektórzy wśród uciskających i prześladujących, jedni wśród torturowanych, inni zaś wśród torturujących czy tych, którzy rozgrzeszają z tortur"79. Ponadto Kościół pomijał w swej działalności i w swo-

74 Tamże, s. 74.

75 „YYuventud y cristianismo en America Latina”. Dokument końcowy seminarium na temat młodzieży zorganizowanego przez Wydział Oświaty CELAM, Bogota 1969, s. 22; cyt. za: G. Gutierrez, Teologia, s. 290.

${ }^{76}$ G. Gutierrez, Teologia, s. 74.

77 Tamże, s. 141.

${ }^{78}$ Inwazja ubogich w Kościele. Wywiad z J. Sobrino, „W drodze” 153-154 (1986), nr 5-6, s. 65-72.

${ }^{79}$ G. Gutierrez, Teologia, s, 145; zob. też S. Markiewicz, Katolicyzm polityczny, s. 125-126. Różne postawy chrześcijan wobec nadziei całkowitego wyzwolenia człowieka rozważa J. Alfaro, Chrześcijańska nadzieja $i$ wyzwolenie człowieka, tłum. P. Leszan, Warszawa 1975 , s. $213-216$. 
im nauczaniu wymiar polityczny Ewangelii, co zdaniem Gutierreza sprawy polityczne i społeczne ograniczało tylko do niewłaściwie rozumianego dobra wspólnego. Akcentowanie jedynie ugodowych aspektów Biblii przyczyniło się do braku zainteresowania społeczną praxis ${ }^{80}$.

Wydaje się, że ojciec teologii wyzwolenia zbyt jednostronnie oceniał Kościół w jego zaangażowaniu społecznym. Jakby zapomniał, że w wielu konkretnych przypadkach zdecydowano się na „przejście od etyki dobroczynności do etyki uczestnictwa", od paternalizmu do służenia ludziom, co wyraźnie popierał Paweł VI ${ }^{81}$. Konkretnym przejawem nowego stylu postępowania Kościoła w Ameryce Łacińskiej było darowanie lub wyprzedaż za symboliczną cenę ziemi należącej do Kościoła, by w ten sposób realizować program rozwoju. Dla ruchu rozwoju społecznego i gospodarczego Kościół poświęcił również wiele swych gmachów, a w trosce o ubogich prowadzi w wielu krajach szkolnictwo, szpitale oraz domy dla starców i sierot ${ }^{82}$. Trzeba również pamiętać o szeregu dokumentach, zwłaszcza z konferencji w Medellin, stanowiących oficjalny głos Kościoła latynoamerykańskiego, w których pamięta się niesprawiedliwość, nienawiść i egoizm. Ciekawa rzecz, że sam Gutierrez często będzie powoływał się na te wypowiedzi, szukając w nich poparcia dla swych tez ${ }^{83}$.

\section{KONTEKST RELIGIJNY}

Ameryka Łacińska, w której mieszka - w porównaniu z innymi kontynentami - największy procent katolików, jest terenem religijności w przeważającej mierze ludowej ${ }^{84}$. Zajęły się nią zarówno konferencja w Medellin jak i konferencja w Puebla, dzięki czemu zaczęto także inaczej, bardziej pozytywnie patrzeć na to zjawisko w Europie. Niewątpliwie „przywrócenie właściwej rangi «religii ludu, religijności ludowej bądź pobożności ludowej» - było według J. C. Scannone - znakiem czasu we współczesnym Kościele" ${ }^{\prime 85}$.

${ }^{80}$ Zob. G. Gutierrez, Teologia, s. 58-59.

${ }^{81}$ Zob. L. Laurentin, Rozwój a zbawienie, tłum. Z. Włodkowa, Warszawa 1972, s. 15.

82 Tamże.

${ }^{83}$ Dokumenty z Medellin raczej opowiadają się za rozwojem, aprobując drogę ewolucji i nie ma w nich mowy o radykalnej rewolucji społecznej. Stanowisko Gutierreza mimo wszystko było przeciwne.

${ }^{84}$ Dodajmy w tym miejscu, że Kościół instytucjonalny - w duchu inkulturacji - przyjął i niejako „ochrzcil” niektóre pogańskie zwyczaje Ameryce Łacińskiej - zob. P. Taras, Religijność ludowa w Kościele Katolickim, "Communio" 42 (1987), nr 6, s. 18-19.

${ }^{85}$ J. C. Scannone, Religijność ludowa, mądrość ludu, teologia ludowa, tłum. G. Ostrowski, "Communio" 42 (1987), nr 6, s. 33. Określenia ujęte w cudzysłów pochodzą z dokumentu z Puebla (III Zgromadzenie Ogólne Episkopatu Ameryki Łacińskiej), nr 444, oraz z Evangelii nuntiandi Pawła VI, n. 48. W cytowanym artykule Scannone pogłębia podjęty temat, analizując wypowiedzi m.in. G. Gutierreza, L. Boffa i J. Sobrino. 
W Ameryce Łacińskiej mamy jednak do czynienia z masowymi ruchami wspólnotowymi, będącymi synkretyzmem najróżniejszych wierzeń. Jeden z owych nurtów aspiruje do tego, aby skompensować sobą jakoby abstrakcyjne i nieprzystosowane do rzeczywistości struktury prawne Kościoła. Ruch ten, zwany spirytyzmem, w samej tylko Brazylii miał w 1968 roku 3500 oficjalnych kaplic i 732784 zwolenników, których zdołano policzyć; jednak w rzeczywistości było ich znacznie więcej ${ }^{86}$. Spirytyzm to wiedza teoretyczna i rzekome praktyczne doświadczenie świata pozaziemskiego, do którego przeniknęło wiele elementów chrześcijańskich, a zwłaszcza postać Chrystusa.

Bardziej znaczące jednak od spirytyzmu są sekty o podłożu animizmu afrykańskiego. W Brazylii istnieje około 100000 takich grup o wierzeniach afrobrazylijskich, a wśród nich kult Xangň i mniej widowiskowy, lecz bardziej złożony kult Umbanda ${ }^{87}$. Obok bóstw afrykańskich czczą one Xangň, czyli św. Jana Chrzciciela, Iemanje, czyli Najświętszą Maryję Pannę z Góry Karmel, i Oguma, którym jest św. Jerzy. Na szczycie hierarchii świętych stoi Orixali - Jezus, u jej dołu zaś znajduje się Exu - zbuntowany anioł. Uczestnicy nabożeństw według tych rytów uważają się za katolików i wiernych Kościoła. Podobna sytuacja synkretyzmu religijnego utrzymuje się w Meksyku. W rezultacie długotrwałej akcji ewangelizacyjnej kolonizatorów cała obecna ludność indiańska tego kraju, z nielicznymi wyjątkami, wyznając oficjalnie katolicyzm, chrzci dzieci, zawiera małżeństwa w Kościele, grzebie swych zmarłych na cmentarzach i obchodzi święta kościelne. Ci sami jednak Indianie, którzy uważają się za gorliwych katolików i zaprzeczają istnieniu w ich świadomości religijnej śladów dawnych wierzeń, zachowali pewne formy religijne oraz praktyki magiczne z czasów przedkortezjańskich ${ }^{88}$. Dzisiaj uważa się, że jedną z przyczyn takiej sytuacji była pewna presja ze strony kolonizatorów i narzucenie nowego europejskiego sposobu życia wraz z katolicyzmem. Na niemożność należytego uświadomienia religijnego wpłynęła również masowość udzielanych chrztów, a także bariery językowe uniemożliwiające należytą katechizację ${ }^{89}$. Dopiero z czasem, gdy mi-

${ }^{86}$ Zob. R. Laurentin, W Ameryce Eacińskiej, s. 91 in.

${ }^{87} \mathrm{~W}$ pobliżu Recife znajduje się sanktuarium, w którym pracuje w pełnym wymiarze godzin i na własny rachunek kapłan tego sanktuarium - Eduim (ten odłam kultu Umbanda nazywa się eduizmem). Wierzy on w swoją misję i jest przekonany, że otrzymał dar od Ducha Świętego. Jego zajęcie ze względu na niezwykłą popularność przynosi mu ogromne zyski; zob. R. Laurentin, W Ameryce Eacińskiej, s. 92-95.

${ }^{88}$ Zob. M. Frankowska, Elementy prehiszpańskie w dzisiejszych wierzeniach Indian Meksyku, w: W kręgu religii krajów pozaeuropejskich, A. Mrozek-Dumanowska (red.), Warszawa 1985, s. 14-16.

${ }^{89}$ Jednego dnia w jednej miejscowości kilku zakonników było w stanie ochrzcić kilka, a nawet kilkanaście tysięcy osób - zob. tamże, s. 16-17. Oczywiście błędem w tym miejscu byłoby ocenianie historii bez uwzględnienia ówczesnego kontekstu historyczno-kulturowego zaistniałych faktów. 
sjonarze opanowali narzecza Indian, zaczęto nauczać prawd wiary i moralności chrześcijańskiej. Synkretyzmowi, o którym mowa, sprzyjały wreszcie podobieństwa istniejące między starymi wierzeniami a nową religią przyniesioną przez białych kolonizatorów ${ }^{90}$. Dlatego właśnie w dzisiejszym katolicyzmie ludowym w Meksyku tkwią jeszcze wyraźnie elementy prehiszpańskie, a z drugiej strony $\mathrm{w}$ wielu ceremoniach indiańskich określanych jako pogańskie widoczne są elementy chrześcijańskie, przy czym nie zawsze można precyzyjnie wyróżnić płaszczyznę dawnych wierzeń indiańskich (tzw. Costumbres), elementy wierzeń ludowych oraz praktyk magicznych śródziemnomorskiego obszaru Europy przyniesionych przez Hiszpanów i wreszcie ortodoksyjną doktrynę Kościoła katolickiego ${ }^{91}$.

Źródłem nowych synkretycznych ideologii indiańskich, wyrażających się w ruchach społeczno-religijnych, było także żarliwe pragnienie Indian uwolnienia się od kolonizacji narzucającej nową religię i nowe układy społeczne ${ }^{92}$. Dzisiaj tego rodzaju sekty mają nieco inną genezę. Przyczyną ich powstania było niezadowolenie z polityczno-ekonomicznej dominacji białych. Do takich niezależnych indiańskich grup wyznaniowych należy na przykład La Iglesia Evangelica Unida, która powstała na przełomie lat pięćdziesiątych i sześćdziesiątych XX wieku, a także ruch Hallelujah, będący mieszaniną obrzędów szamanistycznych i religii chrześcijańskiejej. Swój archaiczny charakter zachowały ponadto pochodzące z Afryki religie Candomblè i Wodu ${ }^{94}$. Wiele nowych indiańskich sekt powstaje na skutek prozelitycznej działalności protestanckich misjonarzy reprezentujących różne pietystyczne i chiliastyczne wyznania ${ }^{95}$.

Nie są także obce Ameryce Łacińskiej ideologie zawierające w sobie elementy millenaryzmu, będące - jak większość wierzeń na tym kontynencie - kompilacją wiary przodków i chrześcijaństwa. Wiążą się z nimi mity katastroficzne i koncepcje eschatologiczne, które głoszą koniec świata, po-

${ }^{90}$ Jest to niewątpliwie argument za jakimś objawieniem pierwotnym - zob. tamże, s. 23. Podobieństwa te są widoczne w obrzędach przypominających chrzest, spowiedź, pewien rodzaj komunii, w wierze w narodziny bóstwa poczętego bez udziału mężczyzny, w dorocznych pielgrzymkach do miejsc kultu, w istnieniu świątyń, ołtarzy, wizerunków czczonych postaci, symboli w kształcie krzyża, koła z rozchodzącymi się promieniami („monstrancja”).

${ }^{91}$ Zob. tamże, s. 44-45.

${ }_{92}^{2}$ Zob. A. Posern-Zieliński, Mit $i$ utopia w ruchach społeczno-religijnych Indian Ameryki Południowej, w: W kręgu religii, s. 49. Przykładem takich dążeń może być ruch proroka Sobce z 1576 r. wśród Indian zamieszkujących okolice Antiquia na terenie dzisiejszej Kolumbii. Ruch ten głosił rychłe nadejście potopu, w wodach którego zginą Hiszpanie - zob. tamże, s. 57.

${ }^{93}$ Zob. tamże, s. 59.

${ }^{94}$ Por. M. Skrzypek, Candomblè, wodu, catimbo - ekstatyczne religie Ameryki Eacińskiej, „Człowiek i Światopogląd” 259 (1987), nr 8, s. 39-51.

${ }_{95}$ Zob. A. Posern-Zieliński, Mit i utopia, s. 59-60. 
wrót złotego wieku i ucieczkę do ziemi bez zła ${ }^{96}$. Te mesjanistyczne kulty obwieszczają powrót Indian do utraconych czasów minionych lub obiecują osiągnięcie pożądanych wytworów materialnej cywilizacji białych ${ }^{97}$. W swym skrajnym odłamie głoszą przemianę tubylców w ludzi białych ze wszystkimi ich przywilejami i zepchnięcie białych na pozycje dyskryminacji ${ }^{98}$.

W wielu spośród omawianych ruchów społeczno-religijnych istotną rolę odgrywa idea zbawcy, oczekiwanie na nadejście Mesjasza i gruntowną zmianę świata. Choć w słabszej formie niż dawniej, Indianie nadal wierzą, że dzięki przychylności sił nadprzyrodzonych dany kult zmieni ich egzystencję na lepszą. Teologia wyzwolenia niewątpliwie na trwałe mogła wpisać się w ten nurt oczekiwań, znajdując podatny grunt dla swoich haseł.

Niski poziom świadomości religijnej i bardzo niewyraźną wiarę spotykamy również wśród wiernych nienależących do żadnej z omawianych sekt i nieopowiadających się po stronie żadnego systemu religijnego poza ortodoksyjną wiarą katolicką. Tutaj także widać szereg elementów pozakatolickich, a nawet pozachrześcijańskich. C. Torres odnotował, że prawie wszyscy znani mu robotnicy zapytani, co to jest Trójca Święta, odpowiadali bez żadnej wątpliwości: „Matka Pana naszego Jezusa Chrystusa”.99.

O płytkości katolicyzmu świadczy życie religijne katolików Ameryki Południowej i Środkowej, a właściwie często brak tego życia. Jeden z misjonarzy polskich pracujących w latach siedemdziesiątych ubiegłego stulecia w Argentynie pisał, że w parafii, w której duszpasterzował, spotkał bardzo niewiele małżeństw ze ślubem kościelnym. Wielu dorosłych nie było nigdy u Pierwszej Komunii Świętej ${ }^{100}$. Z kolei inny duchowny stwierdził, że ignorancja w kwestiach wiary była czasem tak wielka, że na przykład mieszkańcy Amazonii niejednokrotnie wiedzieli tylko to, że są katolikami i że są ochrzczeni ${ }^{101}$.

Niewiedza religijna połączona z religijną obojętnością sprawia, że dla wielu chrzest staje się początkiem i końcem religii. Według relacji jednego z misjonarzy, ludność Ameryki Łacińskiej w większości zupełnie nie rozumie, że istnieją obowiązki wynikające $\mathrm{z}$ wiary ${ }^{102}$. Odzwierciedleniem tego poziomu religijnego katolików latynoamerykańskich jest „ludowo-festynowy” charakter

${ }^{96}$ Zob. tamże, s. 63-73. Istotę tych mitów w wielu swoich publikacjach opisał M. Eliade (zob. np. M. Eliade, Mity, sny i misteria, tłum. K. Kocjan, Warszawa 1999).

${ }^{97}$ Mit cargo np. głosi, że twórcami wszystkich dóbr przemysłowych, którymi dysponują biali, są indiańscy bogowie - zob. A. Posern-Zieliński, Mit i utopia, s. 74.

98 Tzw. mit białej skóry.

${ }^{99}$ Por. J. Eska, Godzina Ameryki Eacińskiej, „Więź" 191 (1974), nr 3, s. 35.

${ }^{100}$ Dane zamieszczone w liście ks. H. Wróbla pt. „Moja parafia w Argentynie”- zob. Misjonarze polscy w świecie, „Nasza rodzina” 1 (1976), numer specjalny, s. 47.

${ }^{101} \mathrm{Z}$ listu ks. M. Knosały, tamże, s. 77.

102 Zob. list ks. H. Kuleszy, tamże, s. 82. 
wielu świąt religijnych, między innymi uroczystości Bożego Ciała. Równie typowy dla mentalności Latynosów, a zwłaszcza dla meksykańskiej obrzędowej pobożności, jest dzień Wszystkich Świętych, który objawia zgodny z wierzeniami azteckimi stosunek do śmierci (całonocne czuwanie rodzin przy grobach zmarłych, ołtarzyki ofiarne, „kwiaty zmarłych”, „chleb zmarłych”). Ludowy, masowy i tradycyjny charakter pobożności meksykańskiej plastycznie ilustruje także odprawianie Drogi Krzyżowej ${ }^{103}$.

Oczywiście obok zasygnalizowanych przejawów religijności ludowej w Ameryce Łacińskiej spotykamy również elity katolickie, ale proporcjonalnie niezbyt liczne. $W$ miastach postępuje bowiem proces laicyzacji, związany podobnie jak w Europie Zachodniej z cywilizacją techniczną i konsumpcyjnym stylem życia. Zmniejsza się liczba uczestniczących w niedzielnych mszach świętych. Najwięcej praktykujących jest wśród kobiet i dzieci. Najbardziej indyferentna jest młodzież $\dot{104}^{104}$.

Główną, choć jednocześnie najmniej widoczną cechą kryzysu katolicyzmu latynoamerykańskiego w latach rozwoju teologii wyzwolenia, było - według R. Laurentina - odrywanie się chrześcijan od istniejących struktur kościelnych: instytucji, prawa i dogmatu, co nie musiało oznaczać jeszcze utraty wiary, choć niewątpliwie mogło do niej doprowadzićc ${ }^{105}$. Człowieka obojętnego na struktury Kościoła Laurentin nazwał „człowiekiem trzecim”106. Obok zjawiska „człowieka trzeciego" w Ameryce Łacińskiej pojawił się także "człowiek czwarty”, czyli chrześcijanin rewolucjonista, który nie chce pozostawać obojętnym wobec struktur Kościoła. Uważa, że ich zmiana drogą spokojnego reformizmu proponowanego przez ostatni Sobór nie zdała egzaminu, dlatego proponuje gwałtowną kontestację $e^{107}$. Do grupy tych ludzi należeli zwolennicy teologii wyzwolenia.

Zjawisko „człowieka piątego” to Kościół podziemny (odpowiednik amerykańskiego Underground Church), który łączy chrześcijan w grupy o zróżnicowanym stopniu wspólnotowości, zwróconej ku Ewangelii i współczesnemu światu, jednak poza ramami oficjalnie przyjętymi ${ }^{108}$.

Kryzys kościoła latynoamerykańskiego w latach największego rozwoju teologii wyzwolenia wyrażał się również w spadku liczby powołań kapłańskich. Jak się wydaje, to zmniejszenie stanu liczebnego kandydatów do kapłaństwa

${ }^{103}$ Zob. T. Wołek, Mexico Catolico. Notatki o Kościele i katolicyzmie meksykańskim, Warszawa-Kraków 1988, s. 31-49.

${ }^{104}$ Zob. J. Eska, Godzina, s. 36.

105 Zob. R. Laurentin, W Ameryce Eacińskiej, s. 15.

106 "Człowiek pierwszy" to według Laurentina konserwatysta pragnący utrzymać instytucje kościelne w ich przedsoborowym wymiarze; "człowiek drugi” zaś to reformator pragnący zmienić je od wewnątrz zgodnie ze wskazaniami Soboru Watykańskiego II; zob. tamże, s. 16.

107 Zob. tamże.

108 Szerzej na ten temat tamże, s. 18-22. 
wiązało się nie tylko $\mathrm{z}$ obowiązkiem celibatu, ale też $\mathrm{z}$ niechęcią wielu do zinstytucjonalizowanych form duszpasterstwa i kryzysem tzw. trzeciego księdza ${ }^{109}$. Ów brak księży wciąż wpływa niezwykle ujemnie na ogólną sytuację religijną kontynentu. W ostatnich dziesięcioleciach ubiegłego wieku tylko w Kolumbii i Ekwadorze wzrost powołań nadążał za wzrostem populacji ${ }^{110}$. Podobno niektórzy księża latynoamerykańscy opuszczali stan duchowny z powodu zarzutów pod adresem "konserwatywnego episkopatu”111.

Tę trudną sytuację złagodziło nieco przybycie do Ameryki Łacińskiej w ciągu kilku ostatnich dziesięcioleci kilkunastu tysięcy kapłanów oraz kilkunastu tysięcy zakonników i zakonnic z Europy i Ameryki Północnej, którzy pozytywnie odpowiedzieli na apel Stolicy Apostolskiej. Nieobecnych na odcinku katechizacji księży zastępują katechiści świeccy, lecz niestety, przeważnie są oni bardzo słabo przygotowani do nauczania ${ }^{112}$.

Kryzys religijności najwyraźniej widoczny jest na przykładzie przeżywających trudny okres i poddawanych często krytyce podstawowych jednostek organizacji kościelnej - parafii. W drugiej połowie poprzedniego stulecia przeciętna parafia obejmowała ponad 15000 wiernych i obszar blisko $1000 \mathrm{~km}^{2}$. Liczniejsze i rozleglejsze były parafie wiejskie ${ }^{113}$. W dalszym ciągu do niektórych wiosek ksiądz jest w stanie dotrzeć raz lub dwa razy w roku ${ }^{114}$.

Przedstawiony w zarysie stan religijności Ameryki Łacińskiej domagał się wypracowania nowych metod duszpasterskich, a w zetknięciu z sytuacją społeczno-ekonomiczną kontynentu - intensywnej pracy Kościoła w dziedzinie charytatywnej. Nabrzmiałe i skomplikowane problemy religijno-pastoralne krajów latynoamerykańskich stały się więc przedmiotem troski papiestwa, szczególnie począwszy od pontyfikatu Piusa XII, z inicjatywy którego zwołano w 1955 roku w Rio de Janeiro pierwszą konferencję episkopatu Ameryki Łacińskiej. Powołała ona stałą Radę Biskupów Ameryki Łaciskiej (Consejo Episcopal Latinoamericana - CELAM), która uświadomiła Kościołowi konieczność zajęcia stanowiska wobec palących kwestii społecznych ${ }^{115}$. Problematyce społeczno-religijnej narodów Ameryki Łacińskiej poświęcono również konferencję CELAM w Medellin (1968 rok) i w Puebla (1979 rok) ${ }^{116}$. Próbowali ją rozwiązać także

109 Zob. tamże, s. 24.

${ }^{110}$ Zob. M. Szafrańska-Brandt, Historia Kościoła, s. 194.

111 Zob. J. Eska, Godzina, s. 37.

112 Zob. list o. F. Konopki, Misjonarze polscy, s. 184.

113 Zob. M. Szafrańska-Brandt, Historia Kościoła, s. 194.

114 Zob. relacja o. F. Konopki, Misjonarze polscy, s. 184.

115 Tradycje tej Rady sięgają schyłku XIX w., kiedy to powstała Kościelna Rada Latynoamerykańska, która w 1890 r. na posiedzeniu w Rzymie postanowiła zwołać tzw. Sobór latynoamerykański. Odbył się on w 1899 r. również w Rzymie; zob. S. Markiewicz, Katolicyzm polityczny, s. 13-15.

116 Szeroko na ten temat tamże, s. 18-132. 
sami wierni, organizując oddolnie, przy pomocy duszpasterzy, tzw. kościelne wspólnoty podstawowe ${ }^{117}$. Kapłani stojący na ich czele uczą czytać i pisać oraz przekazują podstawowe prawdy wiary, o których dotąd w dzielnicach nędzy nikt nie słyszał. We wspólnotach tych działają także osoby świeckie, które osiągnęły odpowiedni stopień dojrzałości religijnej. Tam, gdzie wspólnoty pozbawione zostały księży na skutek prześladowań ze strony państwa, katecheci niejako przemycali z sąsiednich parafii, a nawet diecezji, Najświętszy Sakrament, by udzielić Komunii członkom swej wspólnoty. Jest to, według uświęconego w Ameryce Łacińskiej wyrażenia, „Kościół dający świadectwo”"118. W latach siedemdziesiątych i osiemdziesiątych XX wieku najwięcej tego typu wspólnot było w Brazylii ${ }^{119}$. Niestety równie masowy był tam wspomniany wspólnotowy ruch o tendencjach synkretystycznych.

Kościelne wspólnoty podstawowe rozpoczynają zwykle działalność bez sztywnego systemu organizacyjnego. Tworzą się one spontanicznie w miarę rozwoju grupy, przy czym wybór kierownictwa wspólnoty niestety powoduje decentralizację funkcji proboszcza. Natomiast pozytywnym przejawem ich działania jest niewątpliwie promocja laikatu, a zwłaszcza biednych, słabych, upośledzonych i prześladowanych. Wzorem takiego zaangażowania stała się dla niektórych wspólnot latynoamerykańskich europejska Akcja Katolicka. Z drugiej jednak strony trzeba odnotować fakt, że rozwijające się oddolnie, zwłaszcza w latach sześćdziesiątych ubiegłego stulecia, ruchy religijno-społeczne zbyt wiele przejęły od marksizmu, jak miało to miejsce choćby w lewicowej organizacji katolickiej Młody Kościół, która 11 sierpnia 1968 roku w Santiago de Chile okupowała katedrę, domagając się między innymi „rewolucji w Kościele"120. Podobnie było w przypadku chilijskiego ruchu księży Chrześcijanie na Rzecz Socjalizmu ${ }^{121}$, którą to organizację ostro potępił w swoim czasie przewodniczący

${ }^{117}$ Trudno jest je nawet zdefiniować, gdyż bardzo różnią się między sobą. Trzeba jednak pamiętać, że wspólnoty podstawowe są już owocem religijno-społeczno-politycznego ruchu wyzwoleńczego w Ameryce Łacińskiej. Wspólnoty tego typu istniejące w San Miguelito w Panamie oraz w Kolumbii opisuje R. Laurentin, W Ameryce Eacińskiej, s. 48-61.

${ }^{118}$ Zob. Dzisiejsi prorocy: Ameryki Eacińskiej odczytanie Biblii. Rozmowa z o. Charlesem Antoine, „W drodze” 115 (1983), nr 3, s. 90.

${ }^{119}$ Szczegółowo przedstawia je R. Laurentin, W Ameryce Eacińskiej, s. 91-107; zob. także K. Keler, Eklezjalny charakter wspólnot Leonarda Boffa, "Collectanea Theologica” 3 (1984), s. $33-54$.

${ }^{120}$ Ta 250-osobowa grupa katolików: duchownych i świeckich, podobnie jak ruch C. Torresa, uaktywniła swą działalność w związku z wizytą Pawła VI w Bogocie - S. Markiewicz, Katolicyzm polityczny, s. 37-38.

${ }^{121}$ Zob. tamże, s. 318. Z marksistowskiego punktu widzenia o ruchu chrześcijan na rzecz socjalizmu, jego założeniach, tezach pisze, M. Nowaczyk, Chrześcijanie a socjalizm. Ruch chrześcijański na rzecz socjalizmu, „Euhemer” 106 (1977), nr 4, s. 93-106. 
Konferencji Episkopatu Chile kardynał R. Silva Henriquez ${ }^{122}$, przeciwstawiając się zdecydowanie promarksistowskim tendencjom w Kościele i praktycznemu zbliżeniu chrześcijaństwa z marksizmem ${ }^{123}$.

\section{ZAKOŃCZENIE}

Zrodzona na tle zarysowanej przez nas sytuacji polityczno-gospodarczo-społeczno-religijnej oraz w wyniku tej sytuacji głęboka potrzeba uwolnienia się od zależności politycznej i ekonomicznej, a także pragnienie radykalnej zmiany dotychczasowych warunków życia doprowadziły do utworzenia w Ameryce Łacińskiej różnych ruchów społeczno-politycznych, często o podłożu marksistowskim. Za ich przykład mogą posłużyć chociażby ruchy rewolucyjne na Kubie (w latach 1956-1959) czy w Chile (w roku 1970). Z drugiej strony trzeba pamiętać, że mimo tych tendencji w społeczeństwach latynoamerykańskich silnie zakorzeniona jest, choć czasem bywa zniekształcona, wiara katolicka, a przełom lat sześćdziesiątych i siedemdziesiątych XX stulecia to czas, kiedy do publicznej świadomości dotarły śmiałe wytyczne Soboru Watykańskiego II ${ }^{124}$. Połączenie tych wszystkich czynników, stało się momentem zaistnienia zjawiska, które nazwano teologią wyzwolenia ${ }^{125}$. Zaczęli ją głosić głównie teologowie Ameryki Łacińskiej, wykształceni jednak w Europie i Stanach Zjednoczonych, co dało im nowe spojrzenie teologiczne na problemy własnego kontynentu. Oczywiście nie bez znaczenia dla latynoamerykańskiej teologii pozostawały również określone systemy filozoficzne i koncepcje teologiczne, które stały się jej istotnymi źródłami. Ponadto, skoro teologia wyzwolenia miała być refleksją podejmowaną w świetle Słowa Bożego, niezbędne było w niej odwołanie się do Objawienia. Teologowie wyzwolenia szukali więc inspiracji biblijnych i niejako biblijnych przesłanek, motywacji i uzasadnienia, wytycznych i swoistego alibi dla głoszonych twierdzeń. Pragnęli wreszcie wykazać zgodność prezentowanego przez siebie stanowiska z Urzędem Nauczycielskim Kościoła.

Ostatnie lata rozwoju teologii wyzwolenia zapisały się pod znakiem konfrontacji jej przedstawicieli ze Stolicą Apostolską. W tym kontekście papież Jan Paweł II stwierdził już w czasie II Konferencji Generalnej CELAM w Puebla w roku 1979, że „Kościół nie potrzebuje uciekać się do innych systemów czy ideologii, ażeby kochać i bronić człowieka oraz współpracować w jego wyzwo-

${ }^{122}$ Zob. S. Markiewicz, Katolicyzm polityczny, s. 323-326.

${ }^{123}$ Zob. Cz. Strzeszewski, Ewolucja katolickiej nauki społecznej, Warszawa 1978, s. 252 .

${ }^{124}$ Por. Z. Ziółkowski, Drogi „teologii wyzwolenia”, „Życie i Myśl” 359-360 (1986), nr 7-8, s. 199-200.

${ }^{125}$ Zob. J. Scannone, La teologia della liberazione. Caratterizzazione, correnti, tappe, w: Problemi e prospettive di teologia dogmatica, K. Neufeld (red.), Brescia 1983, s. 393-398. 
leniu [...]. Chce on zachować neutralność wobec przeciwstawnych systemów, by opowiadać się tylko za człowiekiem”"126. Jan Paweł II przypomniał równocześnie biskupom latynoamerykańskim, że pierwszym i niezbywalnym obowiązkiem pasterzy Kościoła jest czuwanie nad czystością doktryny ${ }^{127}$. Kampanię przeciw teologii wyzwolenia rozpoczęli biskupi zachodnioniemieccy, wykorzystując w tym celu swe niemałe wpływy w Ameryce Łacińskiej, osiągane między innymi dzięki pomocy materialnej na rzecz Kościoła latynoamerykańskiego prowadzonej przez organizację Adveniat.

Latynoamerykańscy teologowie wyzwolenia dobrze znali problemy swoich krajów i całego kontynentu: ucisk ekonomiczny i społeczny, kulturalne i religijne zacofanie, arbitralność posługującej się siłą i przemocą władzy politycznej, nędzę i zależność, niesprawiedliwość społeczną i poczucie zagrożenia u zdecydowanej większości społeczeństwa. Kwestiom tym poświęcili wiele uwagi. Oceniali je jednak prawie wyłącznie z punktu widzenia marksistowskiego, uwypuklając sprzeczności między krajami bogatymi a nierozwiniętymi gospodarczo czy antagonizmy między klasą posiadającą a wyzyskiwanymi. Gutierrez pisał, że „klasowa analiza umożliwi nam zrozumienie tego, co rzeczywiście wiąże się z opozycją między krajami uciskanymi a narodami dominującymi”, przy czym „uwzględnienie samej tylko konfrontacji między narodami daje fałszywy obraz sytuacji i ostatecznie przesłania prawdziwą rzeczywistość. Teoria zależności rozwinie się $\mathrm{w}$ niewłaściwym kierunku i doprowadzi do mylnych wniosków, jeżeli analiza nie będzie umieszczona w kontekście światowej walki klas" ${ }^{\prime 28}$. Stosowana przez teologów wyzwolenia marksistowska analiza społeczeństwa uwidoczniała skłonności do socjologizmu głoszącego prymat społeczeństwa nad jednostką. Teologowie wyzwolenia akcentowali wyzwolenie polityczne, ekonomiczne i społeczne (rozpatrywane w kategoriach socjologicznych), będące warunkiem zdobycia nie tylko „wolności od”, lecz także „wolności do": wolności do budowania sprawiedliwego społeczeństwa, własnej historii i braterstwa ludzi ${ }^{129}$. Posługując się marksistowską metodą refleksji nad praxis, zadania teologa utożsamiali jednak z zadaniami socjologa, ekonomisty i polityka, analizując konkretne kwestie polityczne, gospodarcze, społeczne i kulturowe konkretnego kontynentu. Tymczasem teologia musi pozostać nauką oddaną studium prawdy objawionej ${ }^{130}$.

${ }^{126}$ Cyt. za Z. Ziółkowskim, Drogi, s. 203.

${ }^{127}$ Zob. Jan Paweł II, Orędzie do biskupów Ameryki Łacińskiej (Puebla, 28 stycznia 1979 r.), „Chrześcijanin w świecie" 76 (1979), nr 4, s. 8.

${ }^{128}$ G. Gutierrez, Teologia, s. 95.

${ }^{129}$ Zob. J. A. Kłoczowski, Spór o teologie wyzwolenia, „W drodze” 153-154 (1986), nr 5-6, s. 18.

${ }^{130}$ Zob. G. Gutierrez, Prassi di liberazione e fede cristiana, w: La nuova frontiera della teologia in America Latina (= Giornale di teologia, 91), Brescia 1975, s. 44-45; C. Rychlicki, Wobec 
Na przełomie lat siedemdziesiątych i osiemdziesiątych ubiegłego wieku teologia wyzwolenia zdecydowanie przestała być fenomenem tylko lokalnym, stając się problemem całego Kościoła. Środowiska teologiczne i wspólnoty podstawowe, znane dotąd w Europie i Ameryce Łacińskiej, zaczęły rozwijać się w wielu krajach Trzeciego Świata, w Azji i Afryce. Zaczęto jednocześnie zastanawiać się na szerokim forum nad prawowiernością doktryny Gutierreza, Boffa i wielu innych. Pierwsze kroki poczyniła w tej kwestii Międzynarodowa Komisja Teologiczna już w 1976 roku, rozpatrując zjawisko teologii wyzwolenia jako „znaku czasu” z punktu widzenia teologii, eklezjologii i ekumenizmu ${ }^{131}$. We wrześniu 1977 roku, zaś, Komisja ta opublikowała „Deklarację o rozwoju ludzkim i zbawieniu chrześcijańskim", w której, nie kwestionując dobrych intencji teologów wyzwolenia, wskazała na niebezpieczeństwa, jakie mogą powstać w wyniku nadmiernego wiązania teologii ze sprawami politycznymi czy społecznymi, a szczególnie $\mathrm{z}$ marksizmem i leninizmem ${ }^{132}$.

Punktem kulminacyjnym w rozwoju teologii wyzwolenia stały się dwa dokumenty Kongregacji Doktryny Wiary zatwierdzone przez Jana Pawła II. Pierwszym z nich była ogłoszona 3 września 1984 roku „Instrukcja o niektórych aspektach w teologii wyzwolenia” (datowana 26 sierpnia 1984); drugim - zaaprobowana przez Papieża 22 marca 1986 roku „Instrukcja o chrześcijańskiej wolności i wyzwoleniu"133. Radykalna krytyka teologii wyzwolenia dokonana przez Stolicę Apostolską doprowadziła do zasadniczego jej zachwiania i głębokiego kryzysu. Zresztą teologia wyzwolenia od samego początku jawiła się jako system niepełny i nie w pełni spójny, a nawet - w pewnej mierze - prowizoryczny, budząc poważne wątpliwości i krytykę zwłaszcza w świecie teologii europejskiej ${ }^{134}$. Ówczesny prefekt Kongregacji Doktryny Wiary kardynał Joseph Ratzinger na konferencji prasowej, w czasie której dokonano prezentacji drugiej ze wspomnianych instrukcji, powiedział, że „Kościół tym dokumentem wykazuje wolę dokonania rachunku sumienia, wyjaśnienia swojej myśli i nadania kierunków praktykowania wolności ludzkiej [...]. Magisterium Kościoła poczuło się zobowiązane między innymi po pogłębiania interpretacji orędzia chrześcijańskiego wyzwolenia ujawniającego się w nim. Poczuło się zobowiązane do analizy, by interpretować i poprawiać" ${ }^{\prime 135}$. Zaangażowanie, konsekwencja $\mathrm{w}$ działaniu oraz odwaga $\mathrm{w}$ podejmowaniu trudnych i niepopularnych decyzji

teologii wyzwolenia, „Przegląd Katolicki” 23 (1984), s. 7; J. B. Mondin, La Chiesa primizia del Regno, Bologna 1986, s. 184-185.

${ }^{131} \mathrm{~W}$ jej skład wchodzili m.in. H. Urs von Balthasar i J. Alfaro.

${ }^{132}$ Zob. S. Markiewicz, Katolicyzm polityczny, s. 133.

${ }^{133}$ Szerzej na ten temat zob. D. Brzeziński, Stolica Apostolska, s. 97-108.

${ }^{134}$ Por. H. Szymiczek, Gustavo Gutierrez, ojciec teologii wyzwolenia, w: J. Majewski, J. Makowski (red.), Leksykon wielkich teologów XX/XXI wieku, t. 1, Warszawa 2003, s. 133.

135 "L'Osservatore Romano", wyd. włoskie, nr 15 z 10 kwietnia 1986 r., s. 11. 
ze strony Stolicy Apostolskiej na czele z żelaznym Kardynałem, jak nazywano przyszłego papieża, niewątpliwie pozytywnie wspomogły spór ze zwolennikami latynoamerykańskiej teologii wyzwolenia na płaszczyźnie doktrynalnej. Do jej osłabienia i weryfikacji poglądów wielu teologów wyzwolenia w walny sposób przyczyniła się również europejska praxis, tzn. Jesień Ludów w Europie Środkowo-Wschodniej w 1989 roku zakończona upadkiem komunizmu ${ }^{136}$. Natomiast sama sytuacja egzystencjalna narodów latynoamerykańskich - może poza tą polityczną, i to tylko w niektórych krajach - niestety niewiele się zmieniła.

\section{EL CONTEXTO POLÍTICO, ECONÓMICO, SOClAL Y RELIGIOSO DE LA TEOLOGÍA DE LA LIBERACIÓN LATINOAMERICANA}

\section{RIASUNTO}

La teología de la liberación "nació" formalmente en el ańo 1968 durante la II Conferencia General del Episcopado Latinoamericano (CELAM) en Medellín en Colombia, cuando en el documento final de la debate se confirmo "un trato privilegiado de los pobres" por la Iglesia Latinoamericana. En dicha conferencia el papel del consejero teológico ejercía el sacerdote peruano, el profesor de la Facultad de Teología de la Universidad Católica en Lima, D. Gustavo Gutiérrez. Desde su libro - publicado tres ańos después - "Teología de la liberación. Perspectivas" (Lima 1971) tomó las principales ideas y el nombre un movimiento teológico-social, con el cual tuvo que disputar la Iglesia durante unos treinta ańos. El mismo Gutiérrez ha sido reconocido como el padre de la teología de la liberación.

La teología de la liberación, la cual nació en unas concretas condiciones políticosociales y económicas en Latinoamérica como una protestación contra estas condiciones, deseaba abrazar estas condiciones con su actividad liberadora. Postulaba la teología una liberación radical, porque - como subrayaba Gustavo Gutiérrez - los países de Latinoamérica "son mantenidas en el estado de neocolonialismo". La causa de esta situación era una multiforme dependencia de los países latinoamericanos de otros países, sobre todo de los Estados Unidos y de los países de Europa Occidental. Aquella dependencia se manifestaba tanto en relaciones políticas, como en las relaciones económicas presentes

${ }^{136}$ Zdemaskowanie komunizmu oznaczało kompromitację marksizmu. Od tego momentu znacząco malała liczba zwolenników teologii wyzwolenia na kontynencie latynoamerykańskim. W roku 1990 sandiniści stracili władzę w Nikaragui, a stopniowa demokratyzacja życia społeczno-politycznego w wielu krajach Ameryki Łacińskiej coraz bardziej odsuwała widmo rewolucji; zob. I. Dojka, M. Latasiewicz, M. Balon, Benedykt XVI w Polsce. Trwajcie mocni w wierze. Pierwsza pielgrzymka 25-28 maja 2006 roku, Kraków, s. 134. Na przełomie lat osiemdziesiątych i dziewięćdziesiątych ubiegłego stulecia niektórzy z czołowych teologów wyzwolenia - w tym sam Gutierrez - odstąpili od wielu głoszonych uprzednio tez. Ojciec latynoamerykańskiej teologii wyzwolenia w roku 1992 wstąpił do zakonu dominikanów. Obecnie jest wykładowcą m.in. w Papieskim Uniwersytecie św. Tomasza w Rzymie. W Środę Popielcową 2007 r. w rzymskiej bazylice św. Sabiny Benedykt XVI osobiście posypał głowę o. Gutierreza popiołem. 
en el continente latinoamericano. Además era visible en las relaciones sociales. Se trataba aquí de las relaciones político-económicas en los países respectivos de la América Latina, como en la arena mundial. Para obtener una imagen más completa de esta "tierra de contrastes" hay que hacer una referencia a la situación religiosa de los países de Latinoamérica en los ańos setenta i ochenta del siglo pasado, porque también ella entra decididamente en el ambiente de la vida social.

La situación política, económica, social y religiosa, complicada y difícil, siendo un fondo de los acontecimientos en América Latina, ha sido en mismo tiempo una causa directa del nacimiento y desarrollo de la teología de la liberación. La presentación de este fondo forma objeto de esta publicación. 